\title{
Fertilization at planting impairs root system development and drought avoidance of Douglas-fir (Pseudotsuga menziesii) seedlings
}

\author{
Douglass F. JACOBS ${ }^{\mathrm{a}, \mathrm{b} *}$, Robin ROSE ${ }^{\mathrm{a}}$, Diane L. HAASE ${ }^{\mathrm{a}}$, Patricio O. AlZUGARAY ${ }^{\mathrm{a}, \mathrm{c}}$ \\ a Department of Forest Science, Oregon State University, Corvallis, OR, 97331-5752, USA \\ b Current address: Hardwood Tree Improvement and Regeneration Center (HTIRC), Department of Forestry and Natural Resources, \\ Purdue University, West Lafayette, IN, 47907-2061, USA \\ ${ }^{\mathrm{c}}$ Current address: Chilean Forestry Institute INFOR, camino a Coronel Km 7.5, Concepción, Chile
}

(Received 18 July 2003; accepted 12 January 2004)

\begin{abstract}
Douglas-fir (Pseudotsuga menziesii (Mirb.) Franco) seedlings (1+1 bareroot) were divided into $8-13 \mathrm{~cm}^{3}$ and $23-35 \mathrm{~cm}^{3}$ initial root-volume categories and either not fertilized or fertilized with $60 \mathrm{~g}$ Apex ${ }^{\circledR}$ in the planting hole at a drought-prone clearcut site in the Oregon Coast Range, USA. Regardless of initial root volume, fertilized seedlings consistently reached lower predawn xylem water potential ( $\left.\Psi_{\mathrm{xylem}}\right)$ values than non-fertilized seedlings during summer. Roots did not proliferate relative to fertilizer placement and mean values for lateral-root length, root tips, and root biomass were less for fertilized seedlings in each of four vertical root zones. Poor root system development of fertilized seedlings may have been associated with the rapid release of high fertilizer salt concentrations into the rhizosphere. Root-volume growth was positively correlated with $\Psi_{x y l e m}$, emphasizing the importance of new root growth following planting for drought avoidance. Criteria for successful field fertilization must consider the anticipated drought level of the site.
\end{abstract}

seedling / controlled-release fertilizer / root architecture / drought avoidance / Pseudotsuga menziesii

Résumé - La fertilisation à la plantation perturbe le développement du système radiculaire et réduit la résistance à la sécheresse des plants de Douglas (Pseudotsuga menziesii). On a utilisé deux catégories de plants à racines nues $(1+1)$ de Douglas (Pseudotsuga menziesii (Mirb.) Franco) dont le volume initial des racines était respectivement de 8 à $13 \mathrm{~cm}^{3}$ et de 23 à $35 \mathrm{~cm}^{3}$. Ces plants furent installés dans une station de clairière plutôt sèche, située dans la Chaîne côtière de l'Oregon aux USA, et soumis à deux traitements : pas de fertilisation ou fertilisation avec $60 \mathrm{~g} \mathrm{~d}$ 'Apex ${ }^{\circledR}$ introduits dans le trou de plantation. Quelque soit le volume racinaire initial, les plants fertilisés révèlent, au cours de l'été, des valeurs de potentiel hydrique du xylème en fin de nuit ( $\left.\Psi_{x y l e m}\right)$ toujours inférieures à celles obtenues sur plants non fertilisés. Les racines ne se sont pas développées dans les zones en contact avec l'engrais, et les valeurs moyennes de longueur de racines latérales, de nombre de pointes racinaires, et de biomasse racinaire sont inférieures pour les plants fertilisés, dans les quatre plans verticaux. Ce mauvais développement du système racinaire des plants fertilisés peut être associé à la libération rapide d'engrais à forte concentration minérale dans la rhizosphère. La croissance racinaire en volume était corrélée positivement avec le $\Psi_{x y l e m}$ ce qui permet de souligner l'importance de la croissance des racines après plantation pour limiter les effets de la sécheresse. Les critères à adopter pour réussir une opération de fertilisation de terrain doivent donc prendre en considération l'éventuel degré de sécheresse de la station.

plant / engrais à libération contrôlée / architecture racinaire / limitation des effets de sécheresse / Pseudotsuga menziesii

\section{INTRODUCTION}

The success of reforestation operations may be improved if seedlings remain on a growth trajectory following outplanting similar to that in the nursery. Transplant shock often limits the ability of bareroot seedlings to grow vigorously the first one to two years following planting [50]. Fertilization at planting offers a potential means to reduce transplant shock and accelerate initial plantation growth [2,14]. Interest in using controlled-release fertilizer (CRF) at planting has increased over the past decade [26] due to advantages in fertilizer-use efficiency that this fertilizer type offers over conventional fertilizer forms [28]. With a single application, CRF gradually supplies planted seedlings with supplemental nutrition for several months. The ideal CRF product delivers nutrients at a rate matching plant demand, thus improving crop yield and minimizing nutrient loss due to leaching [24, 29].

Reports of seedling growth response to CRF at outplanting vary considerably [8] and one possible reason may be method of CRF application. Fertilizer may be applied to the planting hole, to an adjacent hole, or surface broadcast [8]. To facilitate nutrient uptake, many researchers have recommended applying CRF directly in the planting hole, such that nutrients are released in the immediate vicinity of the root system $[2,12,14$, $23,52]$. However, fertilization in the planting hole may limit root system expansion because roots tend to proliferate in areas

\footnotetext{
* Corresponding author: djacobs@purdue.edu
} 
of high nutrient supply, as observed in numerous controlled experiments $[16,19,21]$. The diffusion of fertilizer salts into the soil solution may also restrict root penetration into subsoil zones, as excessive fertilizer salts kill root apical meristems due to the buildup of toxic ion concentrations and osmotic effects $[18,33]$.

Restrictions to root growth may reduce the ability of seedlings to maintain adequate xylem water potential, termed drought avoidance [59], during the critical establishment period following outplanting. Shoot growth following planting is generally most limited by water availability [10]. When bareroot seedlings are lifted from the nursery, a significant portion of roots, particularly fine roots, are lost [43]. Although there is evidence that planting seedlings with large root volumes may reduce moisture stress and subsequent transplant shock [13, 25], survival of newly-planted seedlings is largely dependent on the rapid extension of roots, which reestablish root-soil contact and thereby absorb water to reduce stress from transpirational loss $[51,54]$. Without efficient water extraction, seedlings continue to transpire, resulting in a condition of physiological drought which contributes to transplant shock and limits wholeplant growth [50].

Following planting, seedlings usually increase root growth relative to shoot growth [37]. A decreased shoot:root ratio allows a greater soil volume to be exploited with relatively less transpirational demand from the shoot $[32,40]$. Fertilization at outplanting when soils are wet, however, may act to increase shoot:root ratios relative to non-fertilized seedlings, as high nutrient availability and sufficient water can limit the need for root expansion [31, 32, 57]. Reduced root expansion relative to shoot growth associated with field fertilization could further increase water stress after soils dry [22].

Few field experiments have studied seedling root proliferation in response to localized nutrient sources. Additionally, little information is available concerning the ability of field-fertilized seedlings to avoid drought immediately following planting. This experiment was designed to examine the influence of initial root volume and field fertilization at a relatively high application rate on seedling root architectural development and drought avoidance. A sub-sample of seedlings in four treatments from a larger experiment [1] was used. We hypothesized that relative to a non-fertilized control, field fertilization would result in (i) greater allocation of biomass to shoot relative to root tissues, (ii) localized root proliferation at the point of CRF placement and decreased subsoil penetration, and (iii) reductions in xylem water potential and stomatal conductance, which would be less pronounced for seedlings with a larger initial root volume.

\section{MATERIALS AND METHODS}

\subsection{Plant material}

Douglas-fir (Pseudotsuga menziesii (Mirb.) Franco) seedlings (Seed Zone 262; Western Forest Tree Seed Council, State of Oregon Tree Seed Zones) were grown for $2 \mathrm{yr}(1+1$ bareroot $)$ using standard nursery practices at Weyerhaeuser's Aurora, OR, USA nursery until lifting in December 1999. Following lifting, seedlings were graded to operational specifications and placed in cold storage at $3{ }^{\circ} \mathrm{C}$. Several
Table I. Nutrient composition of the three Apex ${ }^{\circledR}$ controlled-release fertilizer (CRF) types blended to create the composite fertilizer used in the experiment. Estimated manufacturer timeframe for nutrient release at $21{ }^{\circ} \mathrm{C}$ media temperature is listed for each CRF type.

\begin{tabular}{lcccc}
\hline Nutrient & $\begin{array}{c}\text { CRF 1 } \\
(3-4 \text { month })\end{array}$ & $\begin{array}{c}\text { CRF 2 } \\
(5-6 \text { month })\end{array}$ & $\begin{array}{c}\text { CRF 3 } \\
(8-9 \text { month })\end{array}$ & $\begin{array}{c}\text { CRF } \\
\text { composite }\end{array}$ \\
\cline { 2 - 5 } & \multicolumn{4}{c}{ Composition $(\%)$} \\
\hline $\mathrm{N}\left(\mathrm{NH}_{4}\right)$ & 8.2 & 8.2 & 7.7 & 8.1 \\
$\mathrm{~N}\left(\mathrm{NO}_{3}\right)$ & 10.8 & 10.8 & 10.3 & 10.6 \\
$\mathrm{P}\left(\mathrm{P}_{2} \mathrm{O}_{5}\right)$ & 5.0 & 6.0 & 6.0 & 5.7 \\
$\mathrm{~K}\left(\mathrm{~K}_{2} \mathrm{O}\right)$ & 12.0 & 12.0 & 12.0 & 12.0 \\
$\mathrm{Mg}$ & 1.0 & 0.9 & 0.9 & 0.9 \\
$\mathrm{~S}$ & 1.8 & 1.7 & 1.7 & 1.7 \\
$\mathrm{Fe}$ & 0.5 & 0.5 & 0.5 & 0.5 \\
$\mathrm{Mn}$ & 0.2 & 0.2 & 0.2 & 0.2 \\
$\mathrm{Mo}$ & 0.01 & 0.01 & 0.01 & 0.01 \\
$\mathrm{Zn}$ & 0.06 & 0.06 & 0.05 & 0.05 \\
\hline
\end{tabular}

days before outplanting, seedlings were washed free of soil and measured for root volume by water displacement [9]. Each seedling was then numbered, tagged, and returned to cold storage. Seedlings were divided into categories based on initial root volume. For this study, seedlings examined were from initial root-volume categories of 8 $13 \mathrm{~cm}^{3}(11.2 \pm 0.2)($ mean $\pm \mathrm{SE})(\mathrm{RVC} 1)$ and $23-35 \mathrm{~cm}^{3}(27.0 \pm 0.4)$ (RVC2).

\subsection{Fertilizer treatments}

Seedlings were either non-fertilized or fertilized with $60 \mathrm{~g}$ of a blended CRF (Apex ${ }^{\circledR}$, J.R. Simplot Co., Boise, ID, USA) containing equal amounts of three fertilizers with differing release rates (manufacturer's estimates at $21^{\circ} \mathrm{C}$ media temperature) (Tab. I). By using a $\mathrm{CRF}$ with a mixture of release rates, a more steady supply of nutrients through the desired release period may potentially be achieved. The 60 -g rate was the highest rate used in the larger study [1] and we chose to closely examine seedling development at this rate relative to controls based on previous trials showing negative growth results from similar rates applied at planting on sites subject to dry summers [45]. This CRF consists of prills containing water-soluble nutrients encapsulated within a polyurethane coating, which acts to slow nutrient dissolution. Nutrient release from polymer-coated CRF is primarily controlled by soil temperature and a more rapid rate of release occurs with increasing temperature [34]. Fertilizer was applied to the bottom of the approximately $25-\mathrm{cm}$ planting hole, covered by $1-2 \mathrm{~cm}$ of soil, and the seedling was planted with lateral roots generally extending to within $2 \mathrm{~cm}$ of the fertilizer layer.

Soon after planting, a companion study was installed adjacent to this study to quantify the release of nutrient ions from this CRF [27]. Fertilizer nutrients released relatively rapidly, with $9,22,34$, and $48 \%$ of the composite fertilizer releasing by weight during the first 13,20 , 27 , and 35 weeks, respectively. Specifically, 26, 33, 55, and $65 \%$ of total $\mathrm{N}, 6,15,15$, and $24 \%$ of $\mathrm{P}_{2} \mathrm{O}_{5}$, and $9,16,34$, and $51 \%$ of $\mathrm{K}_{2} \mathrm{O}$ released from the fertilizer during the first 13, 20, 27, and 35 weeks, respectively. During the approximately 48 -week period of the present study, $55 \%$ of the fertilizer released by weight and $73 \%$ of total N, $26 \%$ of $\mathrm{P}_{2} \mathrm{O}_{5}$, and of $63 \%$ of $\mathrm{K}_{2} \mathrm{O}$ released. This was $87-92 \%$ of the total released for all variables during a 62-week sampling period. 


\subsection{Field site}

The outplanting site was in Oregon State University's Dunn Experimental Research Forest $\left(44^{\circ} 43^{\prime} \mathrm{N}, 123^{\circ} 20^{\prime} \mathrm{W}\right)$. This site is on the eastern edge of the Oregon Coast Range, an area characterized by mild winters with heavy precipitation and hot, dry summers. The 38-ha site was clearcut in 1998 and slash was piled and burned shortly thereafter. The aspect of the site was predominantly east, elevation averaged $317 \mathrm{~m}$, slopes ranged from 5-10\%, and the soil was a deep, well-drained silty-clay loam (Waldo series). Seedlings were planted on 19 January 2000 at a $3 \mathrm{~m} \times 3 \mathrm{~m}$ spacing. Immediately following planting, Vexar ${ }^{\circledR}$ tubing was installed to protect seedlings from animal damage.

Pre-plant (30 August 1999) vegetation was controlled on the site using metsulfuron $\left(\right.$ Escort $^{\circledR}, 0.05 \mathrm{~kg} / \mathrm{ha}$ ), sulfometuron (Oust ${ }^{\circledR}, 0.21 \mathrm{~kg} / \mathrm{ha}$ ), glyphosate (Accord ${ }^{\circledR}, 4.67 \mathrm{~L} / \mathrm{ha}$ ), and imazapyr (Arsenal ${ }^{\circledR}, 0.44 \mathrm{~L} / \mathrm{ha}$ ). Subsequent control included hexazinone (Velpar ${ }^{\circledR}, 28$ March 2000, $7.00 \mathrm{~L} / \mathrm{ha}$ ) and clopyralid (Transline ${ }^{\circledR}, 9$ June 2000, $0.73 \mathrm{~L} / \mathrm{ha}$ ). The objective was to attain maximum vegetation control to minimize variation in soil water potential across the site.

\subsection{Measurements}

Seedlings were sampled for predawn xylem water potential $\left(\Psi_{x y l e m}\right)$ on four dates during 2000 (3 July, 31 July, 31 August, and 27 September). Four ( 3 July) or five (all other dates) seedlings from each treatment replication were sampled. A lateral branch from the lower half of the terminal shoot was cut from each seedling and within $5 \mathrm{~min}$, a measurement of $\Psi_{x y l e m}$ using a Scholander-type pressure chamber (Model 600, PMS Instruments, Inc., Corvallis, OR, USA) as per methodology in [15] was recorded.

Morning and afternoon stomatal conductance $\left(g_{s}\right)$ was sampled using a porometer (Model LI-1600, Li-Cor, Inc., Lincoln, NE, USA) on five seedlings from each treatment replication on 28 and 29 September 2000. Two blocks were sampled on the first day and the remaining two blocks on the second day. The weather was clear each day. The same lateral branch on the lower half of the terminal shoot was sampled for both morning (0800-1000 h, solar time) and afternoon (1300-1500 h, solar time) $g_{s}$. The sampled foliage was then excised and placed into cold storage at $3{ }^{\circ} \mathrm{C}$. Leaf area of each foliage sample was assessed using a Panasonic ${ }^{\circledR}$ video image recorder (Model WV-CD20, Matsushita Communication Industrial Co., Ltd., Yokohama, Japan) and AgVision software (Decagon Devices, Inc., Pullman, WA, USA) to adjust gas exchange measurements for variation in leaf area.

On 8 December 2000 , each seedling used for sampling of $\Psi_{\text {xylem }}$ and $g_{s}$ was excavated from the soil with care to preserve the root system and placed into cold storage at $3{ }^{\circ} \mathrm{C}$. Within $7 \mathrm{~d}$, seedlings were measured for height from cotyledon scar to base of terminal bud, root-collar diameter, taproot length, shoot and root volume, and shoot dry weight.

Root architectural development was assessed based on the vertical distribution of roots within the soil profile. Because seedlings were sampled soon after excavation, were dormant when excavated, and had relatively well-lignified root structures, we assumed that roots held approximately the same vertical architectural orientation that was present in the soil. Seedlings were clipped at cotyledon scar and again $5 \mathrm{~cm}$ below this point, which was the minimum distance from cotyledon scar where lateral roots initiated. The remaining roots were then sliced into four $7.5-\mathrm{cm}$ vertical sections (S1-S4), with roots infrequently extending into the deepest section (S4). The fertilizer was placed at a depth of approximately $25 \mathrm{~cm}$ in the soil and therefore generally associated with S3. Roots in each section were divided into tap and lateral roots, with the taproot never extending beyond S2. Within each root section, the number of root tips (white tips $>1 \mathrm{~mm}$ in length) and first-order lateral-root length were assessed. Root sections were then dried at $70{ }^{\circ} \mathrm{C}$ for $72 \mathrm{~h}$ and dry weights of tap and lateral roots were recorded for each vertical root section.

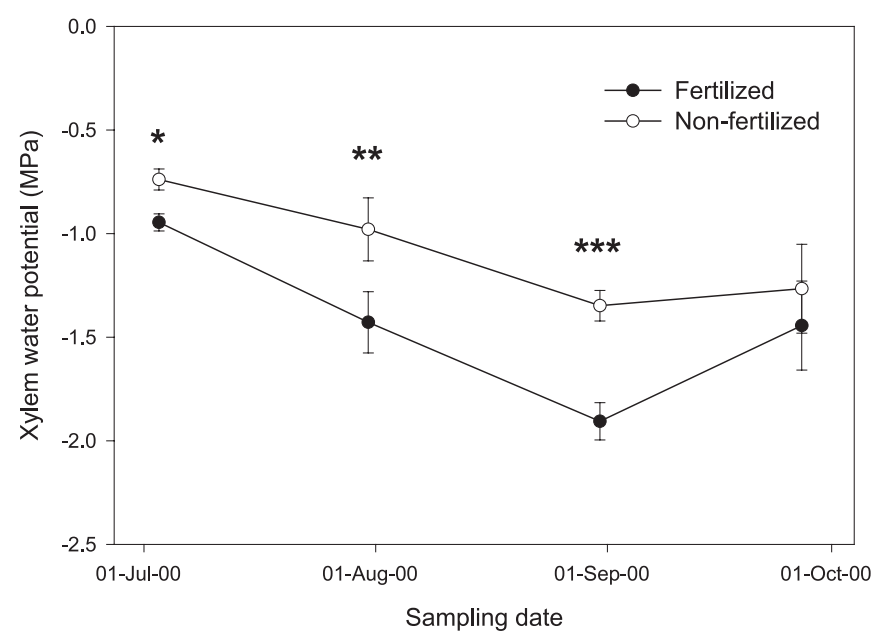

Figure 1. Predawn xylem water potential of fertilized and non-fertilized seedlings (averaged across root-volume categories) at four sampling points. Data points are means, and error bars are SEs. At each sampling point, $* P<0.05$, $* * P<0.01$, and $* * * P<0.001$.

\subsection{Experimental design and statistical analysis}

The experiment was arranged as a randomized complete block design with four blocks and factorial treatments (two initial root-volume categories $\times$ two fertilization rates). Five seedlings were sampled from each treatment within a block (with exception of 3 July $\Psi_{x y l e m}$ ), for a total of 80 seedlings in the experiment. The experimental unit was the group of seedlings within a treatment replication and the sampling unit was the individual seedling.

Data were subjected to analysis of variance (ANOVA) for a randomized complete block design with factorial treatments. Tests for normality and constant variance were performed to ensure the validity of the assumptions of ANOVA and no transformations were necessary. Only in the absence of a significant $(P<0.05$ in $F$ test $)$ root volume $\times$ fertilization rate interaction were the main effects (root volume and fertilization) analyzed to determine if significant differences were present. Fisher's Protected Least Significant Difference procedure was used to identify significant differences $(\alpha=0.05)$ among treatments. Regression analyses were used to determine the relationship between root-volume growth and $\Psi_{\text {xylem }}$ or $g_{s}$. Orthogonal contrasts were used to determine the statistical significance of higher-order regression models but only linear relationships were significant. The mean values of each of the four replicates for each treatment were used in the regression and an adjusted $R^{2}$ value was determined to indicate the fit of the model. SAS ${ }^{\circledR}$ software (SAS Institute Inc., Cary, NC, USA) was used for analysis of all data.

\section{RESULTS}

\subsection{Xylem water potential and stomatal conductance}

Water stress of seedlings in all treatments increased through time during summer (Fig. 1). However, the $\Psi_{x y l e m}$ of fertilized seedlings was lower (i.e., more drought stressed) than non-fertilized seedlings on 3 July $(P=0.0113)$, 31 July $(P=0.0020)$, and 31 August $(P=0.0006)$ (Fig. 1). From 15 June through 
Table II. Mean values \pm SE for seedling morphology of fertilizer treatments (averaged across root-volume categories) and root-volume categories (averaged across fertilization treatments) following excavation in December 2000. For each parameter for either fertilizer treatment or root-volume category, means followed by the same letter in a row did not differ significantly $(P<0.05)$.

\begin{tabular}{|c|c|c|c|c|}
\hline & \multicolumn{2}{|c|}{ Fertilizer treatment } & \multicolumn{2}{|c|}{ Root-volume category } \\
\hline & Non-fertilized & Fertilized & $8-13 \mathrm{~cm}^{3}$ & $23-35 \mathrm{~cm}^{3}$ \\
\hline Height $(\mathrm{cm})$ & $36.0 \pm 1.8 a$ & $37.1 \pm 2.3 a$ & $31.5 \pm 0.7 b$ & $42.0 \pm 1.2 a$ \\
\hline Diameter (mm) & $8.3 \pm 0.5 a$ & $7.8 \pm 0.4 b$ & $7.0 \pm 0.3 b$ & $9.1 \pm 0.2 a$ \\
\hline Taproot length $(\mathrm{cm})$ & $13.6 \pm 0.6 a$ & $12.6 \pm 0.3 a$ & $12.9 \pm 0.5 a$ & $13.3 \pm 0.4 a$ \\
\hline Shoot volume $\left(\mathrm{cm}^{3}\right)$ & $35.3 \pm 6.3 a$ & $29.6 \pm 4.2 a$ & $19.6 \pm 2.3 b$ & $45.3 \pm 3.3 a$ \\
\hline Root volume $\left(\mathrm{cm}^{3}\right)^{1}$ & $27.1 \pm 4.3$ & $18.5 \pm 2.4$ & $15.8 \pm 2.2$ & $29.9 \pm 3.5$ \\
\hline Shoot:root volume & $1.3 \pm 0.1 b$ & $1.6 \pm 0.1 a$ & $1.3 \pm 0.1 b$ & $1.6 \pm 0.1 a$ \\
\hline Shoot dry weight (g) & $12.4 \pm 2.0 a$ & $11.0 \pm 1.6 a$ & $7.4 \pm 0.8 b$ & $16.0 \pm 1.1 a$ \\
\hline Root dry weight $(\mathrm{g})^{1}$ & $9.0 \pm 1.4$ & $6.1 \pm 0.8$ & $5.0 \pm 0.7$ & $10.1 \pm 1.1$ \\
\hline Shoot:root dry weight & $1.4 \pm 0.1 b$ & $1.9 \pm 0.1 a$ & $1.6 \pm 0.1 a$ & $1.7 \pm 0.1 a$ \\
\hline
\end{tabular}

${ }^{1}$ A significant root volume $\times$ fertilization rate interaction occurred.

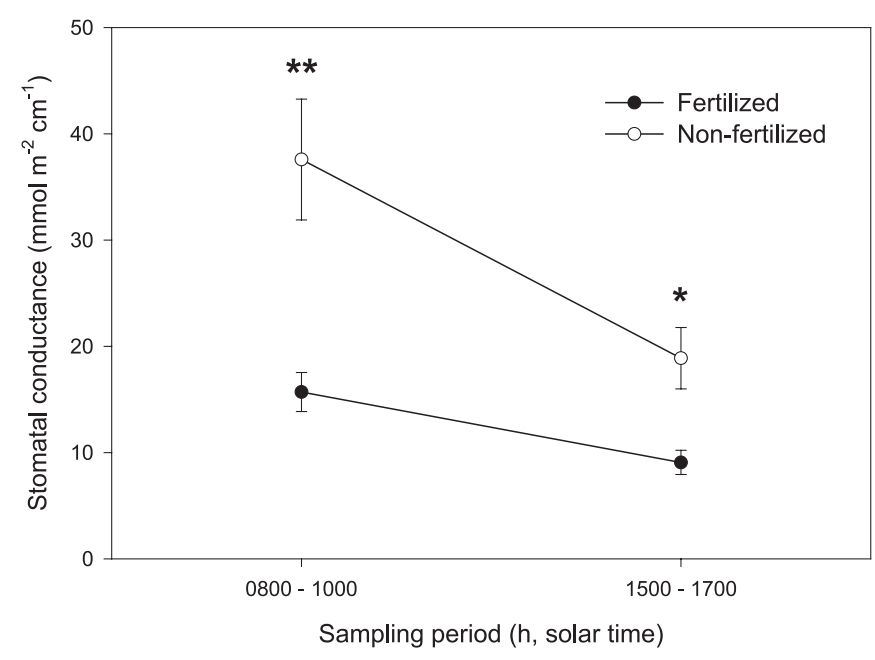

Figure 2. Stomatal conductance for fertilized and non-fertilized seedlings (averaged across root-volume categories) sampled during morning and afternoon hours on 28 and 29 September 2000. Data points are means, and error bars are SEs. At each sampling point, $* P<0.05$ and $* * P<0.01$

1 September, only $0.46 \mathrm{~cm}$ precipitation was recorded in Corvallis, OR, approximately $20 \mathrm{~km}$ south of the study site [47]. In early September, $1.63 \mathrm{~cm}$ of precipitation was recorded in Corvallis, OR. Mean $\Psi_{\text {xylem }}$ on 27 September increased for all treatments, particularly for fertilized seedlings. There was no significant difference in $\Psi_{x y l e m}$ at any sampling between rootvolume categories (data not shown). There was also no significant root volume $\times$ fertilization rate interaction for $\Psi_{x y l e m}$ at any sampling point, indicating that effects of fertilization on $\Psi_{\text {xylem }}$ were not dependent on initial root volume.

Values of $g_{s}$ were higher for non-fertilized seedlings than fertilized seedlings during both morning $(P=0.0052)$ and afternoon $(P=0.0126)$ samplings (Fig. 2$)$. There was no significant difference in $g_{s}$ between root-volume categories during the morning or afternoon (data not shown).

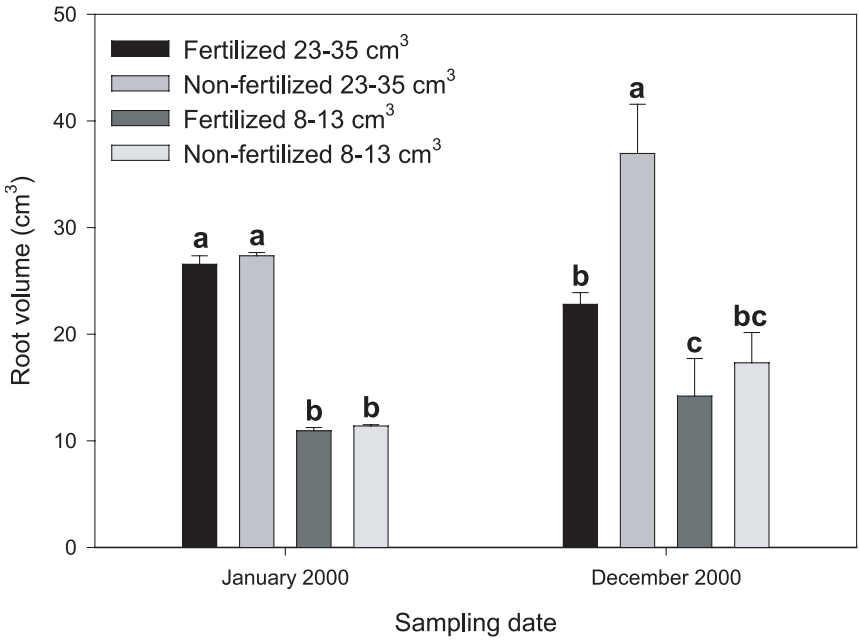

Figure 3. Initial seedling root volume at time of planting (January 2000 ) and following excavation (December 2000). Bars are means, and error bars are SEs. At each sampling point, treatments with the same letter did not differ significantly $(\alpha=0.05)$.

\subsection{Whole plant morphology}

Following seedling excavation in December 2000, root-collar diameter of non-fertilized seedlings was greater than that of fertilized seedlings $(P=0.0270)$ (Tab. II $)$. Shoot:root volume $(P=$ $0.0243)$ and shoot:root dry weight $(P=0.0100)$ were greater for fertilized than for non-fertilized seedlings. Mean height $(P=0.4245)$, shoot volume $(P=0.0516)$, and shoot dry weight $(P=0.0991)$ did not differ between fertilizer treatments. Height, diameter, and shoot volume were greater $(P<0.0001)$ for RVC2 than RVC1 (Tab. II). Shoot:root volume was also greater for seedlings in RVC2 than in RVC1 $(P=0.0421)$, though shoot:root dry weight was not $(P=0.6610)$.

Initial root volume was greater for RVC2 seedlings than RVC1 seedlings $(P<0.0001)$ (Fig. 3). At excavation, means 
Table III. Mean values \pm SE for root architecture parameters of fertilized and non-fertilized seedlings (averaged across root-volume categories) following excavation in December 2000. Root systems were divided into 7.5-cm vertical soil segments (S1-S4), beginning $5 \mathrm{~cm}$ below cotyledon scar, with roots infrequently extending into the deepest section (S4). For each parameter, means followed by the same letter in a row did not differ significantly $(P<0.05)$.

\begin{tabular}{|c|c|c|}
\hline & \multicolumn{2}{|c|}{ Fertilizer treatment } \\
\hline & Non-fertilized & Fertilized \\
\hline S1 number of root tips & $137 \pm 16 a$ & $101 \pm 11 b$ \\
\hline $\mathrm{S} 2$ number of root tips & $126 \pm 15 a$ & $94 \pm 17 a$ \\
\hline S3 number of root tips & $54 \pm 10 a$ & $30 \pm 7 b$ \\
\hline S4 number of root tips & $11 \pm 4 a$ & $4 \pm 2 a$ \\
\hline Total number of root tips & $328 \pm 40 a$ & $229 \pm 34 b$ \\
\hline $\mathrm{S} 1$ lateral-root length $(\mathrm{cm})$ & $94 \pm 7 a$ & $88 \pm 8 a$ \\
\hline S2 lateral-root length $(\mathrm{cm})$ & $95 \pm 10 a$ & $83 \pm 10 a$ \\
\hline S3 lateral-root length $(\mathrm{cm})$ & $36 \pm 7 a$ & $23 \pm 4 a$ \\
\hline $\mathrm{S} 4$ lateral-root length $(\mathrm{cm})$ & $11 \pm 4 a$ & $3 \pm 2 a$ \\
\hline Total root length $(\mathrm{cm})$ & $236 \pm 24 a$ & $197 \pm 21 b$ \\
\hline S1 taproot dry weight (g) & $1.28 \pm 0.16 a$ & $0.88 \pm 0.11 b$ \\
\hline S2 taproot dry weight (g) & $0.04 \pm 0.012 a$ & $0.01 \pm 0.003 b$ \\
\hline Total taproot dry weight $(\mathrm{g})^{1}$ & $2.98 \pm 0.16 a$ & $2.36 \pm 0.10 b$ \\
\hline S1 lateral-root dry weight $(\mathrm{g})^{2}$ & $3.15 \pm 0.54$ & $2.15 \pm 0.30$ \\
\hline $\mathrm{S} 2$ lateral-root dry weight $(\mathrm{g})^{2}$ & $2.13 \pm 0.40$ & $1.28 \pm 0.22$ \\
\hline S3 lateral-root dry weight (g) & $0.64 \pm 0.17 a$ & $0.31 \pm 0.07 a$ \\
\hline S4 lateral-root dry weight (g) & $0.11 \pm 0.04 a$ & $0.03 \pm 0.01 a$ \\
\hline Total lateral-root dry weight $(\mathrm{g})^{2}$ & $6.03 \pm 1.10$ & $3.76 \pm 0.55$ \\
\hline
\end{tabular}

${ }^{1}$ Includes portion of taproot that was excluded in root zone analysis.

2 A significant root volume $\times$ fertilization rate interaction occurred.

for both root volume and root dry weight were greater for nonfertilized than fertilized seedlings (Tab. II). However, there was a significant root volume $\times$ fertilization rate interaction for these parameters $(P=0.0429$ and 0.0250 , respectively). Mean root volume was greatest for the non-fertilized RVC2 treatment (Fig. 3). Interestingly, mean root volume of the fertilized RVC2 treatment did not differ from the non-fertilized RVC1 treatment, despite significant differences at the onset of the study. Treatment differences were similar for root dry weight at excavation, except that mean root dry weight of fertilized RVC2 seedlings was significantly greater than that of non-fertilized RVC1 seedlings (data not shown).

Pre-dawn $\Psi_{\text {xylem }}$ increased linearly with root-volume growth on 3 July $\left(P=0.0016, R^{2}=0.49\right)$ (Fig. 4), 31 July $(P=$ $\left.0.0034, R^{2}=0.43\right)$, and 31 August $\left(P=0.0195, R^{2}=0.28\right)$. Differences in the grouping of data points for non-fertilized and fertilized seedlings reflected the lower root-volume growth and $\Psi_{\text {xylem }}$ for fertilized seedlings (Fig. 4). Both morning $(P=$ $\left.0.0258, R^{2}=0.26\right)$ and afternoon $\left(P=0.0149, R^{2}=0.31\right) g_{s}$ also increased linearly with root-volume growth.

\subsection{Root architecture}

The mean number of root tips tended to be greater for nonfertilized than fertilized seedlings in all root zones (Tab. III). Differences were significant in the $\mathrm{S} 1(P=0.0313)$ and S3 $(P=$ $0.0497)$ root zones, though not in $\mathrm{S} 2(P=0.1113)$ or $\mathrm{S} 4(P=$ $0.1948)$. The total number of root tips was also greater for nonfertilized than fertilized seedlings $(P=0.0327)$ (Tab. III).

Mean total first-order lateral-root length was greater $(P=$ 0.0185 ) (Tab. III) for non-fertilized than fertilized seedlings. Taproot length did not differ between fertilizer treatments $(P=$ 0.1473 ) (Tab. II). Total taproot dry weight, which included the $2.5-\mathrm{cm}$ segment excluded from the root-zone analysis, was greater for non-fertilized than fertilized seedlings $(P=0.0017)$, as was taproot dry weight in $\mathrm{S} 1(P=0.0061)$ and $\mathrm{S} 2(P=$ 0.0296) (Tab. III). Means for lateral-root dry weight tended to be greater for non-fertilized than fertilized seedlings in all root zones, though not statistically significant in S3 $(P=0.0679)$ or S4 $(P=0.1207)($ Tab. III). A root volume $\times$ fertilization rate interaction was detected for lateral-root dry weight in S1 $(P=$ $0.0168), \mathrm{S} 2(P=0.0296)$, and for total lateral-root dry weight 




Figure 4. Regression of root-volume growth on xylem water potential ( $\Psi_{\text {xylem}}$ ) sampled 3 July 2000 for fertilized and non-fertilized seedlings. Regression equation is: $\Psi_{x y l e m}=-0.904+0.017$ (root-volume growth); adjusted $R^{2}=0.49, P=0.0016$.

$(P=0.0377)$ (data not shown). Similar to treatment differences noted for root volume, non-fertilized RVC2 seedlings had the greatest total lateral-root dry weight, while that of the fertilized RVC2 and non-fertilized RVC1 did not differ. The mean lateral-root dry weight of non-fertilized RVC1 did not differ from the fertilized RVC1.

\section{DISCUSSION}

\subsection{Influence of fertilization on root development}

Fertilization clearly inhibited root growth in this study (Tab. III and Fig. 3). This may have been partly associated with the release of fertilizer nutrients acting to decrease the need for new root growth to extract soil nutrients. Under conditions of high nutrient availability and low water stress during spring, seedlings may allocate more biomass to shoots and less to roots since below-ground resources are sufficient for growth [39]. Reports of increased seedling shoot:root ratios in response to fertilization are common $[14,49,57]$ and consistent with the greater shoot:root observed for fertilized seedlings (Tab. II). However, root elongation was not only reduced for fertilized seedlings relative to non-fertilized seedlings, but root volume actually decreased for fertilized RVC2 from time of planting to excavation (mean 26.6 vs. $22.8 \mathrm{~cm}^{3}$ ) (Fig. 3).

Thus, root system development of fertilized seedlings may have been inhibited by the buildup of excessive fertilizer salts in the soil solution, as observed in a previous study in which Douglas-fir seedling roots were unable to penetrate beyond a localized fertilizer layer [33]. Nutrient release of polymercoated CRF is determined by the migration of water vapor through the fertilizer prill membrane, and this process is largely dependent on soil temperature [34]. Soil moisture between 50$100 \%$ of field capacity has essentially no influence on release rate, release is slower at $25 \%$ field capacity, and no release occurs in dry soil [34]. Periodic excavation of fertilizer samples over time indicated that nutrients continued to release into the soil solution at a relatively consistent rate during the summer dry period, and $55 \%$ of total $\mathrm{N}$ had released within 27 weeks of application [27]. As fertilizer nutrients are released, the electrical conductivity (EC) of the soil solution increases and solute potential decreases. Without adequate water to leach nutrients from the soil, concentrations of fertilizer salts likely increased in the soil solution, leading to root dehydration and limiting water uptake. Though magnified under dry soil conditions, this type of physiological drought associated with high solute concentrations can occur even when soil moisture is at field capacity [35].

Conifers, and Douglas-fir in particular, are sensitive to high EC levels [36]. Tolerance to high salt concentrations varies with size of root stock and generally increases with age [61]. Thus, young Douglas-fir seedling roots may be highly vulnerable to injury associated with excessive fertilization, which may help to explain the poor root development of seedlings fertilized at a relatively high rate in this study.

We expected increased root proliferation at or above the position of CRF placement and greater root damage in the lower root sections compared to the upper root sections, as observed in a greenhouse experiment with Douglas-fir seedlings grown in containers [33]. However, there was no distinct proliferation of roots at the approximate position of CRF (vertical root zone S3) or any other root zone, and mean values for root parameters tended to be lower in all root zones for fertilized compared to non-fertilized seedlings (Tab. III). There are several possible explanations for this result. White root tips are anatomically suited for efficient ion uptake [48] and tend to increase in nutrientrich solutions [17]. The lack of increased numbers of root tips, root length, or root biomass in any root zone for fertilized seedlings suggests that nutrient toxicities throughout the rhizosphere associated with rapid nutrient release from this high fertilizer application may have inhibited root proliferation in all zones. Additionally, the greater drought stress incurred by fertilized as compared to non-fertilized seedlings may have reduced wholeplant physiological vigor, further limiting root system development in all root zones. It is also possible that the inherent variation in studying root proliferation relative to fertilizer placement in the field (i.e., precision of planting hole size, fertilizer depth, seedling placement, etc.) and the division of root systems following whole-plant removal from the soil (as compared to separation with soil core intact) limited our ability to detect localized changes in root proliferation.

Seedling root development in the largest root-volume category (RVC2) was more negatively affected by fertilization than in the smallest root-volume category (RVC1) (Fig. 3). This may have been due to increased root-fertilizer contact for seedlings with a larger initial root volume (RVC2). Additionally, this effect was likely magnified by the greater root-volume growth of RVC2 non-fertilized seedlings compared to RVC1 non-fertilized seedlings (Fig. 3). Seedlings with a large initial root volume have higher root growth potential [13], tend to better tolerate transplant shock over time [25], and may have more rapid early growth rates compared to seedlings with a smaller initial root volume $[52,53]$. 


\subsection{Fertilization and moisture availability}

The ability of seedlings to respond positively to fertilization seems to depend on soil moisture availability. Application of Osmocote ${ }^{\circledR}$ CRF improved Sitka spruce (Picea sitchensis (Bong.) Carr.) seedling growth compared to non-fertilized seedlings under well-watered conditions, but decreased growth slightly under droughty conditions [58]. N fertilization at outplanting on sites with low soil moisture reduced growth and survival of Douglas-fir [56] and Monterey pine (Pinus radiata D. Don) [38] seedlings. Survival and dry weight of containergrown Douglas-fir seedlings increased with greater $\mathrm{N}$ levels under well-watered conditions, but decreased under drier conditions [60]. Growth response of eastern white pine (Pinus strobus L.) seedlings at various levels of fertilizer nutrients in solution depended on irrigation schedule, as mean seedling weight decreased with reduced moisture to a greater extent in the fullstrength than the half-strength solution [55].

Poor performance of fertilized seedlings under low soil moisture availability may be associated with the influence of fertilization on drought resistance. Although fertilization of established trees may reduce drought stress [7], contradictory results have often been reported for seedlings. Controlled experiments with lodgepole pine (Pinus contorta Dougl. ex Loud.) [20] and jack pine (Pinus banksiana Lamb.) [57] found that seedlings grown under the lowest $\mathrm{N}$ treatment were better suited to tolerate drought stress than seedlings in higher $\mathrm{N}$ treatments. Similarly, seedlings of loblolly pine (Pinus taeda L.) grown at high $\mathrm{N}$ levels were more negatively affected by drought stress than seedlings grown at moderate $\mathrm{N}$ levels [49]. Despite these reports, the role of $\mathrm{N}$ as a modifier of seedling morphology and physiology in relation to drought resistance remains unclear [57]. Data from the current experiment, however, demonstrated that there may be an interrelationship among fertilization, root system establishment, and drought avoidance.

\subsection{Influence of root development on drought avoidance}

Fertilized seedlings were significantly more drought stressed than non-fertilized seedlings during summer (Fig. 1). This may be at least partly explained by restricted root development (Tab. III and Fig. 3), resulting in access of roots to a smaller volume of soil water. Seedlings have little capacity to store water due to a low ratio of sapwood volume to water transfer rate and lack of other storage reservoirs [44]. Thus, to avoid drought stress following transplant, roots must rapidly extend through the soil profile to extract water. $\mathrm{N}$ fertilization at high rates reduced taproot penetration in jack pine and it was suggested that this would increase susceptibility to drought stress [57]. A significant positive correlation $\left(R^{2}=0.65\right)$ was found between the number of new roots initiated by ponderosa pine (Pinus ponderosa Dougl. ex Laws.) seedlings and predawn leaf water potential [46]. Similarly, leaf water potential of shortleaf pine (Pinus echinata Mill.) increased exponentially with new root projected surface area [5]. In the present study, greater root growth of non-fertilized seedlings was also correlated with increasing ability to avoid drought (Fig. 4). Additionally, nonfertilized seedlings had greater numbers of white root tips
(Tab. III), which are important sites for water uptake as there is anatomically less resistance to water passage [48].

Fertilized seedlings also allocated proportionally more biomass to shoot relative to root tissues than non-fertilized seedlings (Tab. II). Higher shoot:root deter seedling establishment under dry conditions $[4,11]$, because less root area is available to supply a proportionally greater transpirational demand from the shoot.

There were no differences between root volume categories in $\Psi_{x y l e m}$. It was suggested that improved survival after eight growing seasons for ponderosa pine seedlings with a larger initial root volume on a harsh, dry site was associated with greater access of larger root systems to limited water and nutrients [53]. However, no difference at 95 or $115 \mathrm{~d}$ following transplant in predawn $\Psi_{x y l e m}$ was reported among Douglas-fir seedlings graded into different root volume classes [25]. Thus, targeting for a larger initial root volume in Douglas-fir seedlings may not reduce drought avoidance at least during the first season following planting.

As $\Psi_{\text {xylem }}$ decreases, $g_{s}$ also declines [41] and photosynthesis is directly related to $g_{s}$ [30]. Although healthy, established Douglas-fir trees can survive drought stress to -11 MPa, photosynthesis typically begins to decline at $-1 \mathrm{MPa}$ [6]. A seasonal decline in $g_{s}$ of Douglas-fir seedlings of nearly $50 \%$ was reported when $\Psi_{x y l e m}$ reached $-1.5 \mathrm{MPa}$ [42]. In the present study, mean predawn $\Psi_{\text {xylem }}$ of fertilized seedlings reached $-1.9 \mathrm{MPa}$ for fertilized seedlings on 31 August, compared to $-1.3 \mathrm{MPa}$ for non-fertilized seedlings (Fig. 1). Values of $g_{s}$ were also significantly lower for fertilized than non-fertilized seedlings at the end of September, even when $\Psi_{x y l e m}$ no longer differed between treatments (Fig. 2). The low $\Psi_{\text {xylem }}$ and $g_{s}$ for seedlings in all treatments illustrates the severity of drought on this site. However, non-fertilized seedlings were better able to avoid drought stress, which likely enabled these seedlings to photosynthesize at higher rates than fertilized seedlings. Fertilized seedlings may have been less able to balance the energy costs associated with respiration with gains from photosynthesis, increasing dependence on stored carbohydrates. It is well documented that plant growth is restricted under conditions of prolonged drought $[3,4,25]$. Thus, limitations to drought avoidance during the summer following transplant associated with excessive fertilization may act to reduce seedling growth and survival in subsequent years.

\section{CONCLUSIONS}

The high rate of fertilization at outplanting substantially modified seedling root system development during establishment. No localized root proliferation associated with placement of fertilizer in the planting hole was observed. Mean values for root system parameters of fertilized seedlings were depressed in all root zones compared to non-fertilized seedlings, which may have been associated with the rapid release of high concentrations of fertilizer salts in the soil solution. Further quantitative research examining both specific changes in rhizosphere EC levels associated with CRF release and corresponding rates of plant nutrient uptake is needed to determine threshold EC values which maximize soil nutrient availability, while not deterring root proliferation or causing plant toxicities. 
Fertilized seedlings were less able to avoid drought stress following transplant, as indicated by significantly lower predawn $\Psi_{x y l e m}$ values during summer. This was likely a function of greater allocation of biomass to shoot relative to root tissues and the reductions in root biomass, first-order lateral-root length, and number of white root tips, which limited the ability of fertilized seedlings to exploit water from the soil profile. In an effort to conserve water, fertilized seedlings had lower rates of $g_{s}$ and were, therefore, unable to photosynthesize to the degree of non-fertilized seedlings.

These results illustrate the importance of adjusting field fertilization protocols for the anticipated degree of moisture stress on the site. The $60 \mathrm{~g}$ fertilization rate applied to the vicinity of the root zone inhibited root system proliferation, thereby limiting the ability of seedlings to avoid drought stress. To improve seedling response to field fertilization on droughty sites, alternative methods of fertilizer placement may be preferable. Additional strategies for minimizing potential drought stress may include use of conservative CRF application rates, employing a CRF product with longer timeframe for nutrient release, or use of a CRF type with mechanisms of nutrient release that are more dependent on soil moisture availability (e.g., urea formaldehyde or isobutylidene diurea). Consideration should also be given to delaying fertilizer application to one or two years following planting when seedling root systems have established. On sites where drought is extreme, it may be advisable to avoid field fertilization entirely.

Acknowledgements: Financial support for this research was provided by the Nursery Technology Cooperative. Seedlings for this experiment were donated by Weyerhaeuser Co. and fertilizer was donated by J.R. Simplot Co. Eric Lamfers assisted with preparing the outplanting site and planting coordination. Barbara Bond, J.C. Domec, and Nate McDowell provided consultation regarding physiological measurements. Owen Burney, Sam Dalebout, Christine Jacobs, and Nicole Jacobs assisted with measurements.

\section{REFERENCES}

[1] Alzugaray P.J., Effects of fertilization at the time of planting on field performance of $1+1$ Douglas-fir (Pseudotsuga menziesii (Mirb.) Franco) seedlings, M.S. thesis, Oregon State University, 2002.

[2] Austin R.C., Strand R.F., The use of slowly soluble fertilizers in forest planting in the Pacific Northwest, J. For. 58 (1960) 619-627.

[3] Becker C.A., Mroz G.D., Fuller L.G., The effects of plant moisture stress on red pine (Pinus resinosa) seedling growth and establishment, Can. J. For. Res. 17 (1987) 813-820.

[4] Bongarten B.C., Teskey R.O., Dry weight partitioning and its relationship to productivity in loblolly pine seedlings from seven sources, For. Sci. 33 (1987) 255-267.

[5] Brissette J.C., Chambers J.L., Leaf water status and root system water flux of shortleaf pine (Pinus echinata Mill.) seedlings in relation to new root growth after transplanting, Tree Physiol. 11 (1992) 289-303.

[6] Brix H., Effects of plant water stress on photosynthesis and survival of four conifers, Can. J. For. Res. 9 (1979) 160-165.

[7] Brix H., Mitchell A.K., Thinning and nitrogen fertilization effects on soil and tree water stress in a Douglas-fir stand, Can. J. For. Res. 16 (1986) 1334-1338.

[8] Brockley R.P., The effects of fertilization on the early growth of planted seedlings: a problem analysis, Forestry Canada, Ottawa, Ont. For. Resour. Dev. Agree. Rep. 0835-0752:011, 1988.
[9] Burdett A.N., A nondestructive method for measuring the volume of intact plant parts, Can. J. For. Res. 9 (1979) 120-122.

[10] Burdett A.N., Herring L.H., Thompson C.F., Early growth of planted spruce, Can. J. For. Res. 14 (1984) 644-651.

[11] Cannell M.G.R., Bridgwater F.E., Greenwood M.S., Seedling growth rates, water stress responses and root-shoot relationships related to eight-year volumes among families of Pinus taeda L., Silvae Genet. 27 (1978) 237-248.

[12] Carlson W.C., Effects of controlled -release fertilizers on the shoot and root development of outplanted western hemlock (Tsuga heterophylla Raf. Sarg.) seedlings, Can. J. For. Res. 11 (1981) 752-757.

[13] Carlson W.C., Root system considerations in the quality of loblolly pine seedlings, South. J. Appl. For. 10 (1986) 87-92.

[14] Carlson W.C., Preisig C.L., Effects of controlled-release fertilizers on the shoot and root development of Douglas-fir seedlings, Can. J. For. Res. 11 (1981) 230-242.

[15] Cleary B.D., Zaerr J.B., Pressure chamber techniques for monitoring and evaluating seedling water status, N.Z. J. For. Sci. 10 (1980) 133-141.

[16] Coutts M.P., Philipson J.J., The influence of mineral nutrition on the root development of trees: I. The growth of sitka spruce with divided root systems, J. Exp. Bot. 27 (1976) 1102-1111.

[17] Coutts M.P., Philipson J.J., The influence of mineral nutrition on the root development of trees: III. Plasticity of root growth in response to changes in the nutrient environment, J. Exp. Bot. 28 (1977) 1071-1075.

[18] Drew M.C., Comparison of the effects of a localized supply of phosphate, nitrate, ammonium and potassium on the growth of the seminal root system and the shoot, in barley, New Phytol. 75 (1975) 479-490.

[19] Drew M.C., Saker L.R., Nutrient supply and the growth of the seminal root system in barley: II. Localized, compensatory increases in lateral root growth and rates of nitrate uptake when nitrate supply is restricted to only part of the root system, J. Exp. Bot. 26 (1975) 79-90.

[20] Etter H.M., Growth, metabolic components and drought survival of lodgepole pine seedlings at three nitrate levels, Can. J. Plant Sci. 49 (1969) 393-402.

[21] Friend A.L., Eide M.R., Hinckley T.M., Nitrogen stress alters root proliferation in Douglas-fir seedlings, Can. J. For. Res. 20 (1990) $1524-1529$.

[22] Gilman E.F., Tree root growth and development. II. Response to culture, management and planting, J. Environ. Hortic. 8 (1990) 220-227.

[23] Gleason J.F., Duryea M., Rose R., Atkinson M., Nursery and field fertilization of $2+0$ ponderosa pine seedlings: the effect on morphology, physiology, and field performance, Can. J. For. Res. 20 (1990) 1766-1772.

[24] Goertz H.M., Controlled release technology, in: Howe-Grant M. (Ed.), Encyclopedia of chemical technology, 4th ed., John Wiley \& Sons, Inc., New York, NY, 1993, pp. 254-274.

[25] Haase D.L., Rose R., Soil moisture stress induces transplant shock in stored and unstored $2+0$ Douglas-fir seedlings of varying root volumes, For. Sci. 39 (1993) 275-294

[26] Haase D.L., Rose R. (Eds.), Symposium Proceedings: Forest Seedling Nutrition From the Nursery to the Field, 28-29 Oct. 1997, Nursery Technology Cooperative, Oregon State University, Corvallis, OR, 1997.

[27] Haase D.L., Alzugaray P.O., Rose R., Nutrient release patterns of four controlled-release fertilizers (unpublished data).

[28] Hangs R.D., Knight J.D., Van Rees K.C.J., Nitrogen accumulation by conifer seedlings and competitor species from ${ }^{15}$ nitrogen-labeled controlled-release fertilizer, Soil Sci. Soc. Am. J. 67 (2003) 300-308.

[29] Hauck R.D., Slow-release and bioinhibitor-amended nitrogen fertilizers, in: Engelstad O.P. (Ed.), Fertilizer Technology and Use. Soil Science Society of America, Inc., Madison, WI, 1985, pp. 293-322.

[30] Hinckley T.M., Austin R.G., Aubuchon R.R., Metcalf C.L., Roberts J.E., Leaf conductance and photosynthesis in four species of the oak-hickory forest type, For. Sci. 24 (1978) 73-84. 
[31] Imo M., Timmer V.R., Growth, nutrient allocation and water relations of mesquite (Prosopis chilensis) seedlings at differing fertilization schedules, For. Ecol. Manage. 55 (1992) 279-294.

[32] Imo M., Timmer V.R., Nitrogen uptake of mesquite seedlings at conventional and exponential fertilization schedules, Soil Sci. Soc. Am. J. 56 (1992) 927-934.

[33] Jacobs D.F., Rose R., Haase D.L., Development of Douglas-fir seedling root architecture in response to localized nutrient supply, Can. J. For. Res. 33 (2003) 118-125.

[34] Kochba M., Gambash S., Avnimelech Y., Studies on slow release fertilizers. 1. Effects of temperature, moisture, and water vapour pressure, Soil Sci. 149 (1990) 339-343.

[35] Kozlowski T.T., Soil moisture and absorption of water by tree roots, J. Arbor. 13 (1987) 39-46.

[36] Landis T.D., Tinus R.W., McDonald S.E., Barnett J.P., The container tree nursery manual: Vol. 4, Seedling nutrition and irrigation, US Dep. Agric. Handb. 674, 1989.

[37] Ledig F.T., Bormann F.H., Wenger K.F., The distribution of dry matter growth between shoot and roots in loblolly pine, Bot. Gaz. 131 (1970) 349-359.

[38] Linder S., Benson M.L., Myers B.J., Raison R.J., Canopy dynamics and growth of Pinus radiata. I. Effects of irrigation and fertilization during a drought, Can. J. For. Res. 17 (1987) 1157-1165.

[39] Marschner H., Effect of internal and external factors on root growth and development, in: Marschner H. (Ed.), Mineral nutrition of higher plants, 2nd ed. Academic Press, New York, 1995, pp. 508-536.

[40] McMillin J.D., Wagner M.R., Effects of water stress on biomass partitioning of ponderosa pine seedlings during primary root growth and shoot growth periods, For. Sci. 41 (1995) 594-610.

[41] Meinzer F.C., The effect of vapor pressure on stomatal control of gas exchange in Douglas-fir saplings, Oecologia 54 (1982) 236-242.

[42] Murphy E.M., Ferrell W.K., Diurnal and seasonal changes in leaf conductance, xylem water potential and abscisic acid of Douglasfir in five habitat types, For. Sci. 28 (1982) 627-638.

[43] Nambiar E.K.S., Root configuration and root regeneration in Pinus radiata seedlings, N.Z. J. For. Sci. 10 (1980) 249-263.

[44] Newton M., Preest D.S., Growth and water relations of Douglas fir (Pseudotsuga menziesii) seedlings under different weed control regimes, Weed Sci. 36 (1988) 653-662.

[45] Nursery Technology Cooperative, Fertilization with slow-release fertilizers on the Warm Springs Indian Reservation, in: Nursery Technology Cooperative 1999-2000 Annual Report, Oregon State University, Corvallis, OR, 2000, pp. 13-18.

[46] Omi S.K., Yoder B., Rose R., Fall lifting and long-term freezer storage of ponderosa pine seedlings: effects on post-storage leaf water potential, stomatal conductance, and root growth potential, Tree Physiol. 8 (1991) 315-325.

[47] Oregon Climate Service, Archived daily observations: Corvallis, OR [online], College of Oceanic and Atmospheric Sciences, Oregon State University, (02002, Available from http://www.ocs.orst.edu/corv-dly.html (updated 27 June 2002; cited 24 November 2002) 2002

[48] Peterson C.A., Enstone D.E., Taylor J.H., Pine root structure and its potential significance for root function, Plant Soil 217 (1999) 205-213.

[49] Pharis R.P., Kramer P.J., The effect of nitrogen and drought on loblolly pine seedlings, For. Sci. 10 (1964) 143-150.

[50] Rietveld R., Transplanting stress in bareroot conifer seedlings: Its development and progression to establishment, North. J. Appl. For. 6 (1989) 99-107.

[51] Ritchie G.A., Dunlap J.R., Root growth potential - its development and expression in forest tree seedlings, N.Z. J. For. Sci. 10 (1980) 218-248.

[52] Rose R., Atkinson M., Gleason J., Sabin T., Root volume as a grading criterion to improve field performance of Douglas-fir seedlings, New For. 5 (1991) 195-209.

[53] Rose R., Haase D.L., Kroiher F., Sabin T., Root volume and growth of ponderosa pine and Douglas-fir seedlings: a summary of eight growing seasons, West. J. Appl. For. 12 (1997) 69-73.

[54] Sands R., Transplanting stress in radiata pine, Aust. For. Res. 14 (1984) 67-72.

[55] Schomacher C.E., Growth and the foliar nutrition of white pine seedlings as influenced by simultaneous changes in moisture and nutrient supply, Soil Sci. Soc. Am. Proc. 33 (1969) 614-618.

[56] Smith H.S.D., Can fertilization reduce planting-check of Douglasfir? For. Chron. 42 (1966) 87-89.

[57] Tan W.X., Hogan G.D., Physiological and morphological responses to nitrogen limitation in jack pine seedlings: potential implications for drought tolerance, New For. 14 (1997) 19-31.

[58] Townend J., Effects of elevated CO2, water and nutrients on Picea sitchensis (Bong.) Carr. seedlings, New Phytol. 130 (1995) 193-206.

[59] Van den Driessche R., Effects of nutrients on stock performance in the forest, in: van den Driessche R. (Ed.), Mineral nutrition of conifer seedlings, CRC Press, Boca Raton, FL, 1991, pp. 229-260.

[60] Van den Driessche R., Changes in drought resistance and root growth capacity of container seedlings in response to nursery drought, nitrogen, and potassium treatments, Can. J. For. Res. 22 (1992) 740-749.

[61] Zekri M., Seedling emergence, growth and mineral concentration of three citrus rootstocks under salt stress, J. Plant Nutr. 16 (1993) $1555-1568$. 